\title{
EFFICIENCY INSTITUTION BAITUL MAAL TAMWILL IN THE WESTDISTRICT BANDUNG
}

\author{
Annisa Nur Hakim, A Jajang W Mahri, Aas Nurasyiah \\ Indonesia Univerisity of Education
}

E-mail: annisanhk@student.upi.edu, ajajangwmhari@upi.edu, asnur.fna@upi.edu

\begin{abstract}
Baitul Maal Wat Tamwil has experienced development in recent years. However, based on BMT performance data in West Bandung regency is less optimal. It is known that there are one efficient BMTs in West Bandung Regency and three BMTs that are inefficient. The cause of BMT's less optimal performance is inefficiency in operational activities. This study aims to determine the level of efficiency of BMT in West Bandung 2011-2017 period and find out the causes of inefficiency. This study uses secondary data from four BMTs in West Bandung District which are sampled. The research method used is descriptive method with Data Envelopment Analysis (DEA) analysis technique which is to measure the level of efficiency of a company. Input variables used are operating expenses, total assets, and TPF. Furthermore, the output variables used are SHU, income, and financing. Based on the results of research conducted, the conditions of the BMT in West Bandung Regency have not been perfectly efficient. There are three BMTs that have experienced inefficiencies including BMT Dana Ukhuwah, BMT Mustama, and BMT Rabbani.
\end{abstract}

Keywords. Efficiency, Baitul Maal Wat Tamwil, Data Envelopment Analysis.

\section{INTRODUCTION}

Baitul Maal Wat Tamwil is an institution or party (al jihat) that has a special duty to handle all the assets of the people, both in the form of state income and expenses. According to Kholim (2004) the number of BMTs and their distribution to date there is no accurate data. The three regions that have the largest number of BMTs in Indonesia are West Java with 637 BMTs where 433 only report their activities to PINBUK, then the second is East Java with 600 BMTs where there are 519 BMTs that report their activities, and those occupying the third position are Central Java with 513 BMTs where only 447 BMTs reported their activities.

According to Atiqi (2014) historically around 1990 BMT grew rapidly with a total of around 4,000 BMTs operating in Indonesia. However, most BMTs do not work well and some of them have collapsed. This shows that the growth of BMT is not consistent with the development of the quality of its performance. However, most BMTs do not work well and some of them have collapsed. This shows that the growth of BMT is not consistent with the development of the quality of its performance. Therefore, the performance of the BMT needs to be evaluated to find outproblems and inefficiencies importantespecially evaluating the efficiency and effectiveness of the BMT in order to demonstrate the health of this institution that can be effective for the management of its Islamic wealth.

Based on Sumiyanto's book (2008) the sustainability ofunsafe Baitul Maal wat Tamwil in Indonesia is poor management, management, human resources unable to work professionally, unable to attract public trust, capital difficulties and so on. Based on the results of an interview with Lutfi (2018) Chairperson Gakopsyah explained that the general condition of the BMT is currently reorganizing its institutions. Therefore serious BMTs will reorganize BMTs while BMTs that are not serious will dissolve the BMT. The general underlying problems of BMT when managing BMT is that the Bank wants to position BMT as a mini Bank. Most people still misunderstand that BMT or cooperative is a bank. The majority of the Baitul Maal operations of the BMT have not yet run, not 
all people want to deposit zakat, infaq, sadaqoh through BMT. If it already exists, it is likely that much can be done by BMT.

To measure this performance, efficiency is needed. Efficiency is needed for every company to do things right (doing the thing right). Efficiency is the ratio of output and input related to achieving output maximumwith a number of inputs. So if theratio output the input greater, the efficiency is said to be higher (Pasaribu, Bakce, \& Dewi, 2016)

The concept of efficiency was first introduced by Farrell in 1957. According to Farrell, efficiency in a company is related with how to produce thelevel of output maximumwith anumber of inputs certain. Islam recommends that in sharia economic activities human behavior bermuamalah must pay attention to efficiency. Islam does not see the growth of wealth as. Islam does not only regulate worship, but daily life is regulated in Islam for financial efficiency. In this modern economic system, money is a medium of exchange that can facilitate the spinning process of the wheels of economic development. Money allows trade and economic transactions to be carried out efficiently (Juliana, 2017).As the word of Allah SWT has explained in the Qur'an Surah Al-Isra verse 27:

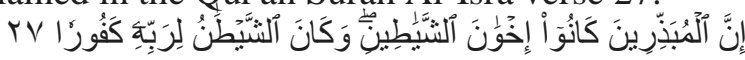

27. Surely the squanderers are the fellows of the Shaitans and the Shaitan is ever ungrateful to his Lord.

Based on research conducted by Atiqi Chollisni Nasution (2014), M. Mahbubi Ali and Ascarya (2010), Badranaya (2017), Tahir and CheTahrim (2013), Erasmus Fabian Kipesha (2012) shows that BMTs in several regions have not been able to achieve efficiency in various periods. The measuring tool used to determine the level of efficiency is Data Envelopment Analysis (DEA). Data Envelopment Analysis (DEA) was first introduced by Charnes in 1978. The purpose of this approach is to measure the relative efficiency of each DMU (Decision Making Unit). The measuring tool used to determine the level of efficiency is Data Envelopment Analysis (DEA). Data Envelopment Analysis (DEA) was first introduced by Charnes in 1978.

Efficiency analysis of the Non-Bank Financial Institution industry (NBFI) is very important, given the very tight competition between institutions. One way is to measure the efficiency of BMT institutions. This analysis can be done in several BMTs in Indonesia as a medium for comparing performance among financial institutions. The comparison will be very beneficial for several parties, including banks and non-bank financial institutions and the general public. Based on the problems that have been described above, the authors felt the need to conduct research on, "The Efficiency of theInstitution Baitul Maal Wat Tamwil in West Bandung Regency".

\section{LITERATURE REVIEW}

Research on the Efficiency of theInstitution Tamul Wat Tamwil has been carried out both domestically and abroad. From these studies different conclusions. The difference in research results occurs because it uses different research methods and periods. The analytical tool most widely used by researchers to measure the level of efficiency of theInstitute Baitul Maal Wat Tamwil is Data Envelopment Analysis (DEA). What distinguishes previous research with this research is located on the object under study, this research was conducted at BMT in West Bandung Regency and annual reports for the period 2011-2017.

Research conducted by M. Mahbubi Ali and Ascarya (2010) discusses BMT Efficiency with Two Stage DEA approach (Case Study of BMT MMU and BMG UGT Sidogiri Branch Offices). The input variables are profit sharing expenses, personnel costs, and general and administrative expenses, and the output variables are TPF, total financing, operating income, and other operating income. As a result, theefficiency of overall technical BMT MMU (0.84) and BMT UGT (0.88) in 2008 was still not optimal. The cause of BMT MMU inefficiency is, the amount of funding is less than optimal. While the causes of inefficient BMT UGT Sidogiri are third-party funds that are less than optimal.

Next Atiqi (2015), discusses the efficiency of BMT efforts towards the management of Islamic wealth using the DEA method. The input variables are fixed assets, total capital andoutput variables namely the disbursement of loans and the amount of profit sharing. The efficiency results found that the efficiency of BMT UGT Sidogiri and BMT Al Hikmah Bangsri had the highest efficiency scores 
of the fourteen BMTs operating in the poorest provinces. Inefficiency is caused by the quality of human resources and also the absence of supporting funds (DPK).

Tahir and CheTahrim (2013) discuss about comparing the efficiency of microfinance institutions in five countries in ASEAN with the DEA method. The input variables are total assets and operating costs and the output variables are, gross loans and the number of active borrowers. The results found that financial institutions micro finance in Vietnam is relatively more efficient than the microfinance institutions of Laos, Indonesia, Cambodia and the Philippines.

Erasmus (2012) discusses the efficiency of microfinance institutions in East Africa. The input variables used are total assets, Personnel, operating costs and output variables namely gross loan portfolio, financial income. The results found Tanzania, Kenya, Uganda, Rwanda, Burundi on average to have higher efficiency scores. This finding also shows that on average banks and non-bank financial institutions are relatively more efficient compared to NGOs and cooperatives.

Ben Soltane Bassem (2008) discusses Efficiency of Microfinance Institutions in the Mediterranean An Application of DEA. The input variable is the number of employees and total assets and the output variable is the number of borrowers and ROA. The results found 35 microfinance institutions in the Mediterranean zone prove that eight institutions are relatively efficient, and present a substantial level of average efficiency and evolutionary potential referring to technical efficiency. The results also found that the size of MFIs had a negative effect on the efficiency of medium-sized MFIs more efficiently than the leading ones.

\section{RESEARCH METHODOLOGY}

The research method used in this study is a comparative descriptive method. The comparative approach of this study will compare the financial performance of BMTs in West Bandung Regency. This study will describe and measure the level of efficiency of BMT institutions in West Bandung Regency in the period 2011-2017. This study aims to determine the level of efficiency of BMT institutions in West Bandung Regency and what are the causes of BMT inefficiency in West Bandung Regency so that some improvement efforts can be made to improve next period.

This efficiency analysis method requires data consisting of inputs and outputs of a Decision Making Unit (DMU). Operating variables used in this study can be seen from the following table:

Table 1.1

Operational Variables

\begin{tabular}{|c|c|c|c|}
\hline Input / & Theoretical Concepts & Indicator & Scale \\
\hline \multirow[t]{3}{*}{$\begin{array}{l}\text { Variables } \\
\text { Input }\end{array}$} & $\begin{array}{l}\text { Operational expenses are costs } \\
\text { incurred in the implementation of } \\
\text { savings and loan services selling } \\
\text { activities by Islamic cooperatives } \\
\text { to members (Cokrohadisumarto, } \\
\text { Ismail, \& Kartiko A, 2016) }\end{array}$ & $\begin{array}{l}\text { Operating expenses: } \\
\text { administrative and general } \\
\text { costs, promotion costs, office } \\
\text { stationery costs, telephone costs, } \\
\text { depreciation and amortization } \\
\text { costs, electricity costs, official } \\
\text { travel expenses related to } \\
\text { savings and loan activities, } \\
\text { employee salary costs. } \\
\text { Cooperative expenses: the cost } \\
\text { of education and training of } \\
\text { cooperative human resources, } \\
\text { the cost of meeting } \\
\text { organizations, the cost of } \\
\text { developing work areas }\end{array}$ & TheRatio \\
\hline & $\begin{array}{l}\text { Total Asset is the amount of } \\
\text { assets owned by BMT measured } \\
\text { in millions of rupiah. Total assets } \\
\text { is derived from current assets and } \\
\text { fixed assets (Princess \& Mulazid) }\end{array}$ & $\begin{array}{l}\text { Assets lancer } \\
\text { Fixed assets }\end{array}$ & ratio \\
\hline & $\begin{array}{l}\text { DPK funds from the community } \\
\text { gathered with savings products }\end{array}$ & $\begin{array}{l}\text { Voluntary savings or savings, } \\
\text { voluntary time deposits, }\end{array}$ & Ratio of \\
\hline
\end{tabular}




\begin{tabular}{|c|c|c|c|}
\hline & $\begin{array}{l}\text { Baitul Maal wa Tamwil } \\
\text { (Goodwill, 2016). }\end{array}$ & $\begin{array}{l}\text { principal savings, mandatory } \\
\text { savings, grants, other non- } \\
\text { binding funds (participation } \\
\text { capital), external capital }\end{array}$ & \\
\hline \multirow[t]{3}{*}{$\begin{array}{l}\text { VariableOut } \\
\text { puts }\end{array}$} & $\begin{array}{l}\text { Remaining Operating Results } \\
\text { (SHU) are all main operating } \\
\text { income that has been deducted by } \\
\text { expenses or expenses from } \\
\text { Operational activities, business } \\
\text { and other expenses after tax } \\
\text { (Cokrohadisumarto, Ismail, \& } \\
\text { Kartiko A, 2016) }\end{array}$ & $\begin{array}{l}\text { Remaining Operating Results } \\
\text { (SHU) }\end{array}$ & Ratio \\
\hline & $\begin{array}{l}\text { Revenue is income received in } \\
\text { connection with the } \\
\text { implementation of business } \\
\text { activities which are not the main } \\
\text { activities of a cooperative } \\
\text { business. Among them: profit } \\
\text { from asset sales } \\
\text { (Cokrohadisumarto, Ismail, \& } \\
\text { Kartiko A, 2016). }\end{array}$ & $\begin{array}{l}\text { Operating income and other } \\
\text { income }\end{array}$ & Ratios \\
\hline & $\begin{array}{l}\text { Financing are funding provided } \\
\text { by another party to support } \\
\text { planned investments, both self- } \\
\text { employed and institutional } \\
\text { (Yuningrum, 2012). }\end{array}$ & Financing & Ratio \\
\hline
\end{tabular}

\section{Source: Processed by the author}

Data collection techniques used in this study are through study literature with examine journals and books related to theory and documentation studies to obtain information or secondary data and compile information derived from the annual financial statements of BMT in West Bandung Regency in the period 2011-2017. The tools to analyze the data in this study are tools help computers with themethod Data Envolepment Analysis (DEA)for measuring and analyzing data BMT efficiency. As for software which is used as a support in this research issoftware MaxDEA 6.1.

Decision Making Unit (DMU) is a business unit that will be tested for efficiency. DMU in this research is BMT in West Bandung Regency, namely Mustama BMT, El Dana Benefit BMT, BMT Rabbani, and BMT Dana Ukhuwah. This research will use an intermediation approach. Intermediation is considered the most appropriate because BMT is an intermediary institution or intermediary between the excess funds and those who lack funds. Determination of the approach affects the use ofvariables input-output. Thevariables input used in this study are operational expenses, total assets and third party funds. Thevariables output used are SHU, income, and financing. Data sourced fromfinancial statements time series. The DEA model used is the BCC-VRS model with the assumption that BMT does not work in optimal conditions.

\section{RESULTS AND DISCUSSION}

Efficiency is an effort to optimize the output obtained, by usingresources input certainthat are most appropriate. According to Farell, the efficiency of the company consists of two components, namely technical efficiency and allocative efficiency. These two measures are then combined into economic efficiency (Tanjung \& Devi, 2013). The factors that cause the first efficiency is, if with input the sameproduces greater output. Second, inputs smallercan produce output the same. And the third, with input a largecan produce output a larger. Efficiency in a company, especially within Financial institutions are one of the popular work parameters to measure its performance. This is due to efficiency which is the answer to difficulty in calculating performance measures, such as the level of technology efficiency, allocation, and whole efficiency (Badranaya, 2017)

According to Tanjung and Devi (2013) the formula for the results of the efficiency value will show a scale of 0-1 (zero to one), where if the efficiency results show "0" then the business units 
tested are very inefficient. While the value of "1" indicates that the business unit is very efficient. The DEA method will provide information about the actual number, the number obtained in the current time frame and the target number, which is expected to enable the company to reach the most efficient point. which is the result of calculating the level of efficiency of BMT in West Bandung regency period 2011- 2017.

Table 1.2

Efficiency Level BMT in West Bandung regency period 2011- 2017

\begin{tabular}{|r|l|r|r|r|r|r|r|r|}
\hline No & Name BMT in the & \multicolumn{7}{|c|}{ Year } \\
\cline { 3 - 9 } & $\begin{array}{l}\text { District of West } \\
\text { Bandung }\end{array}$ & $\mathbf{2 0 1 1}$ & $\mathbf{2 0 1 2}$ & $\mathbf{2 0 1 3}$ & $\mathbf{2 0 1 4}$ & $\mathbf{2 0 1 5}$ & $\mathbf{2 0 1 6}$ & $\mathbf{2 0 1 7}$ \\
\hline 1. & $\begin{array}{l}\text { Funds BMT } \\
\text { Ukhuwwat }\end{array}$ & 0,93 & 0.94 & 0.94 & 0.97 & 0.99 & 1 & 1 \\
\hline 2. & BMT Mustama & 1 & 1 & 0.95 & 1 & 0.97 & 0.92 & 0.86 \\
\hline 3. & BMT El Benefit Fund & 1 & 1 & 1 & 1 & 1 & 1 & 1 \\
\hline 4. & BMT Rabbani & 0.77 & 0.92 & 1 & 0.95 & 0.83 & 0.79 & 0.78 \\
\hline
\end{tabular}

Source: Data processed with Max Dea 6.1 (2018)

Based on the results of the above study, it can be seen that the average value of BMT efficiency in Bandung Regency West in 2011-2017 is still very low. Seen table 1.2 BMT efficiency levels in West Bandung regency from year to year continues to fluctuate. Of the four BMTs in West Bandung Regency studied from 2011-2017, just in 2015 only one BMT which reached the efficient point of BMT El Dana Benefit. While BMT Dana Ukhuwah, BMT Mustama, BMT Rabbani experienced varying levels of efficiency.

Based on research that has been done, in the period 2011-2017 it is known that there is only one BMT in West Bandung Regency which achieved a perfect level of efficiency. Overall BMTs in West Bandung Regency are still inefficient, but there are BMTs in West Bandung Regency that have begun to approach efficiency, including BMT Ukhuwah funds with an average value of 0.969 while BMTs with the highest inefficiency value are Rabbani BMTs with an average of 0.864 .

Factors that cause inefficiency are divided into two. Namely input factors andfactors output. Thefactors input dominantcausing BMT inefficiencies in West Bandung Regency are total assets and DPK. The inefficiency of total assets is due to the fact that a higher realization rate has not been found compared to the specified target number and the accumulation of deposits is still less than optimal so it must be reduced to be effective and achieve output the specified.

Thefactors output that cause inefficiencies are SHU, income, and financing. SHU obtained on average still in under the specified target. So BMTs that have SHU below the target or are low enough must maximize it. Revenue achievement is still below the specified target number. Revenues on BMT are related to financing distribution. As the results of the study note that the funding channeled by BMT is still relatively small. Distribution of BMT financing is still below the specified target. This happens because of the precautionary principle by BMT before providing financing. However, caution should be taken by BMT not to impede the targets that have been determined. In addition to these problems regarding the distribution of financing in BMT. One of them is the non-operation of financing distribution in BMT Rabbani by switching to the real sector (Lutfi, 2018).

Efforts to increase the value of the efficiency of total assets can be done by improving fund management so that the company is productive but remains in a safe condition such as BMT El Dana Benefits. Providing education to BMT members that the members are the owners of the company where the company in question is BMT. Efforts to increase DPK include promoting advertisements by distributing brochures, forms and attaching information, an active approach to holding meetings / recitals, presentations at all times and opportunities, and a direct approach to members.

Efforts to improve the efficiency of SHU can be done with the participation of members in the field of decision making, in the field of capital and in the field of service use. Efforts that can be made to improve income are also related to improvements in financing. So an effort is needed to socialize BMT financing products so that their products are known and used by the public. Increasing BMT efficiency values in West Bandung Regency can use the CRS, IRS and DRS classification methods. 


\section{CONCLUSION}

The level of efficiency of BMTs in West Bandung Regency has not reached perfect efficiency in the period 2011-2017. During the last seven, only one BMT has been found to reach an efficiency value of 1 namely the El Dana Benefit BMT. In addition there are three BMTs that are still experiencing inefficiencies, namely the Ukhuwah Fund BMT, Mustama BMT, Rabbani BMT. The causes of BMT inefficiency in West Bandung Regency are divided into two namely, input factors andfactors output. Input factors that cause inefficiencies are total assets and third party funds. While the output factors that cause inefficiencies are SHU, income and financing factors.

Based on the results of the efficiency research on BMT in West Bandung Regency, BMT with a high amount of assets and earlier operational activities do not guarantee the level of efficiency.

\section{REFERENCE}

Ali, M. M., \& Ascarya. (2010). Analisis Efisiensi Baitul Maal Wat Tamwil Dengan Pendekatan Two Stage Data Envelopment Analysis (Studi Kasus Kantor Cabang BMT MMU Dan BMT UGT Sidogiri. Tazkia Islamic Finance \& Business Review Vol 5 No.2 , 110- 125.

Ascarya, \& Illiyyin, A. R. (2013). Efisiensi Model BMT Vs Koperasi. Iqtishodia, 23-25.

Badranaya, D. (2017). Efficiency of Financing in Sharia Cooperatives. Etikonomi, 249- 264.

Bassem, B. S. (2008). Efficiency of Microfinance Institutions in the Mediterranean: An Application of DEA. Mediterranean and Middle East Papers , 343-354.

Cokrohadisumarto, W. M., Ismail, A. G., \& K. W. (2016). BMT Praktik dan Kasus. Jakarta: PT RajaGrafindo Persada.

Juliana. (2017). Uang Dalam Pandangan Islam. Amwaluna, Vol. 1 No. 2, 217- 230.

Khan, A. (2014). Efficiency Measure of Insurance v/s Tak ful Firms Using DEA Approach: A Case of Pakistan. Islamic Economic Studies Vol. 22, No. 1, May, 2014, 139-158.

Kholim, M. (2004). Eksistensi Baitul Maal wat Tamwil dan Permasalahan dalam Operasionalisasinya (Studi Di Provinsi Jawa Tengah). Master Thesis Program Pascasarjana.

Kipesha, E. F. (2012). Efficiency of Microfinance Institutions in East Africa A Data Envelopment Analysis. European Journal of Business and Management ISSN 2222- 1905 Vol 4, No 17, 7788.

Lutfi. (2018, Mei Senin). Jumlah Baitul Maal wa Tamwil di Kabupaten Bandung Barat. (A. N. Hakim, Interviewer)

Muhibah, I. (2016). Efisiensi Baitul Maal Watamwil Kota Tasikmalaya Periode 2011- 2015 Pendekatan Stochastic Frontier Analysis (SFA) Derivasi Fungsi Profit dan BOPO. Journal of Economics and Business Aseanomics (JEBA), 235- 257.

Nasution, A. C. (2014). Efficiency of Baitul Maal Wa Tamwil (BMT) An Effort Towards Islamic Wealth Management In Microfinance Institution . Malaysia: International Islamic University of Malaysia. 
Pasaribu, A., Bakce, D., \& Dewi, N. (2016). Analisis Efisiensi Produksi Usaha Tani Kelapa Di Kecamatan Keritang Kabupaten Indragiri Hilir. JOM Faperta Vol.3 No. 1 , 1- 11.

Putri, M. S., \& Mulazid, A. S. (n.d.). Analisis Efisiensi Bank Umum Syariah (BUS) di Indonesia Dengan Menggunakan Metode Data Envelopment Analysis (DEA) Periode 2013-2015. UIN Syarif Hidayatullah Jakarta, 1-17.

Sakti, A. (2013). Pemetaan Kondisi dan Potensi BMT: Kemitraan dalam rangka Memperluas Pasar \& Jangkauan Pelayanan Bank Syariah kepada Usaha Mikro. Jurnal al-Muzara'ah, Vol. I, No. $1,1-18$.

Sumiyanto, A. (2008). BMT Menuju Koperasi Modern: panduan untuk pemilik, pengelola, dan pemerhati baitul maal wa tamwil dalam for,at koperasi: dilengkapi panduan lengkap \& praktis pembentukan dan pengelolaan BMT. ISES Pub.

Tahir, I. M., \& CheTahrim, S. N. (2013). Efficiency Analysis of Microfinance Institutions in ASEAN A DEA Approach. Business Management Dynamics Vol.3, No.4, 13-23.

Tanjung, H., \& Devi, A. (2013). Metodologi Penelitian Ekonomi Islam. Jakarta : Gramata Publishing

Yuningrum, H. (2012). Mengukur Kinerja Operasional BMT Pada Tahun 2010 Ditinjau Dari Segi Efisiensi Dengan Data Envelopment Analysis (DEA) (Studi Kasus BMT Di Kota Semarang). Economica Vol II/ Edisi 2, 111-128Tikawati. (2012). Implementasi Good Corporate Governance Pada Lembaga Keuangan Syariah (Perbankan Syariah). Jurnal Pemikiran Hukum Islam Vol. 10, No.2, 118-126. 